\title{
Illustrations
}

Between pages 136 and 137

Nandi, Shiva's vehicle-Chamundi Hill, Mysore

Feeder Canal off the Ramaswamy Canal

Feeder Canal, another section

Paddy field after being harvested

Jaggery-making

Harvesting

A bullock cart on the road along the Tank

Collecting alluvium from the Tank in summer

The Basava Temple

The deity Narasimha being taken in procession during the annual festival at Harigolu village

Cheluvadi, hereditary Harijan servant of the high castes, showing the symbol of his office

Ornamented door in a rich landowner's house (left);

a detail of the carving (below)

\section{Maps and Diagrams}

Rampura in Karnataka State

Facing page 1

Notional map of Rampura

Sketch of the Bullock House, 1948

The agricultural year in Rampura and its

relation to social and religious activities

Canal system in Rampura region 